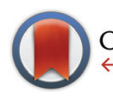

CrossMark \&lick for updates

Cite this: Dalton Trans., 2016, 45 10118

Received 14th April 2016, Accepted 28th April 2016

DOI: $10.1039 / c 6 d t 01439 a$

www.rsc.org/dalton

\section{Stabilization of molecular lanthanide polysulfides by bulky scorpionate ligands $\uparrow:$}

\author{
Marcel Kühling, ${ }^{a}$ Robert McDonald, ${ }^{b}$ Phil Liebing, ${ }^{a}$ Liane Hilfert, ${ }^{a}$ \\ Michael J. Ferguson, ${ }^{\mathrm{b}}$ Josef Takats ${ }^{{ }^{\mathrm{b}}}$ and Frank T. Edelmann ${ }^{* a}$
}

Well-defined lanthanide polysulfide complexes containing $\mathrm{S}_{4}{ }^{2-}$ and $\mathrm{S}_{5}{ }^{2-}$ ligands, the samarium(III) pentasulfide complex $\mathrm{Sm}\left(\mathrm{Tp}^{\mathrm{i} \mathrm{Pr}_{2}}\right)\left(\kappa^{1}-3,5-{ }^{\mathrm{i}} \mathrm{Pr}_{2} \mathrm{Hpz}\right)\left(\mathrm{S}_{5}\right)$ and the tetrasulfide-bridged binuclear ytterbium(III) complex $\left(\mu-\mathrm{S}_{4}\right)\left[\mathrm{Yb}\left(\mathrm{Tp}^{\mathrm{i} \mathrm{Pr}_{2}}\right)\left(\kappa^{1}-3,5-{ }^{\mathrm{i}} \mathrm{Pr}_{2} \mathrm{Hpz}\right)\left(\kappa^{2}-3,5-{ }^{\mathrm{i}} \mathrm{Pr}_{2} \mathrm{pz}\right)\right]_{2}$ $\left(\operatorname{Tp}^{\mathrm{iPr}} \mathrm{Pr}_{2}=\right.$ hydro-tris(3,5-diisopropylpyrazolyl)borate), have been synthesized and structurally characterized by single-crystal X-ray diffraction.

\section{Introduction}

Polysulfides of the rare-earth metals ( $\mathrm{Ln}$ ) have been known for over 100 years. ${ }^{1,2}$ The most common types of these materials are $\mathrm{LnS}_{2}{ }^{3,4}$ and $\mathrm{LnS}_{2-x},{ }^{5,6}$ but well-defined, more complicated species such as $\operatorname{Ln}_{8} S_{14.9}(\operatorname{Ln}=$ Dy, Ho) have also been described. $^{7}$ The synthetic routes to such lanthanide polysulfides normally require high-temperature and/or high-pressure techniques. $^{8,9}$ In sharp contrast, molecular lanthanide complexes containing polysulfide ligands remain little explored, although a number of interesting inorganic ${ }^{10-17}$ and organometallic $^{18-20}$ sulfido clusters have been reported in recent years. Most of these contain the $\mathrm{S}_{2}{ }^{2-}$ ligand, while $\left(\mathrm{Cp}_{2}{ }_{2} \mathrm{Sm}\right)_{2}\left(\mathrm{~S}_{3}\right)(\mathrm{THF}) \quad\left(\mathrm{Cp}^{*}=\right.$ pentamethylcyclo-pentadienyl $)$ appears to be the only lanthanide complex with an $\mathrm{S}_{3}{ }^{2-}$ ligand. ${ }^{10}$ We describe here the formation and structural characterization of the first lanthanide polysulfide complexes containing the $\mathrm{S}_{4}{ }^{2-}$ and $\mathrm{S}_{5}{ }^{2-}$ ligands, namely $\mathrm{Sm}\left(\mathrm{Tp}^{\mathrm{iPr}}\right)\left(\kappa^{1}-3,5{ }^{\mathrm{i}}{ }^{\mathrm{P}} \mathrm{Pr}_{2} \mathrm{Hpz}\right)$ $\left(\mathrm{S}_{5}\right)$ (3) and $\left(\mu-\mathrm{S}_{4}\right)\left[\mathrm{Yb}\left(\mathrm{Tp}^{\mathrm{iPr}}\right)\left(\kappa^{1}-3,5-{ }^{\mathrm{i}} \mathrm{Pr}_{2} \mathrm{Hpz}\right)\left(\kappa^{2}-3,5-{ }^{\mathrm{i}} \mathrm{Pr}_{2} \mathrm{pz}\right)\right]_{2}$

\footnotetext{
${ }^{a}$ Chemisches Institut der Otto-von-Guericke-Universität, 39106 Magdeburg, Germany. E-mail: frank.edelmann@ovgu.de

${ }^{b}$ Department of Chemistry, University of Alberta, Edmonton, Alberta, AB, Canada T6G 2G2. E-mail: joe.takats@ualberta.ca

$\dagger$ Dedicated to Professor R. Dieter Fischer on the occasion of his 80th birthday. \$Electronic supplementary information (ESI) available: Full crystallographic data for 3, 4, and 5. CCDC 1472924, 1472923 and 1472811. For ESI and crystallographic data in CIF or other electronic format see DOI: 10.1039/c6dt01439a
}

$\left(\mathrm{Tp}^{\mathrm{iPr}}=\right.$ hydro-tris(3,5-diisopropylpyrazolyl)borate; $3,5-{ }^{\mathrm{i}} \mathrm{Pr}_{2} \mathrm{pz}=$ 3,5-diiso-propylpyrazolate; 3,5 - ${ }^{\mathrm{i}} \mathrm{Pr}_{2} \mathrm{Hpz}=3,5$-diisopropylpyrazole), which are stabilized by bulky scorpionate ligands.

It is well established from the chemistry of the bent metallocenes $\mathrm{Cp}^{*}{ }_{2} \mathrm{Ln}(\mathrm{Ln}=\mathrm{Sm}, \mathrm{Eu}, \mathrm{Yb})$ that these strongly reducing lanthanide(II) precursors are easily oxidized by elemental sulfur or diorganodisulfides (RSSR), resulting in the formation of trivalent metallocenes containing $\mathrm{S}^{2-}$ or $\mathrm{RS}^{-}$ligands. ${ }^{10,21,22}$ Thus, it was of interest to investigate the reactivity of the recently reported "bent sandwich-like" divalent lanthanide scorpionates, $\operatorname{Ln}\left(\mathrm{Tp}^{\mathrm{iPr}}\right)_{2}(\mathrm{Ln}=\mathrm{Sm}, \mathrm{Eu}, \mathrm{Tm}, \mathrm{Yb})^{23,24}$ with $\mathrm{S}_{8}$ with a view to establish whether the presence of bulky scorpionate ligands might lead to the formation of polysulfide-ligated species. Here we report the results of the reactions of $\operatorname{Ln}\left(\operatorname{Tp}^{\mathrm{iPr}}\right)_{2}(\operatorname{Ln}=\operatorname{Sm}(\mathbf{1}), \mathrm{Yb}(2))$ with sulfur.

\section{Synthesis and characterization}

The reaction of $\mathrm{Sm}\left(\mathrm{Tp}^{\mathrm{iPr}}\right)_{2}$ (1) with sulfur was first carried out in toluene. Addition of one equiv. of $S_{8}$ to a toluene solution of 1 at r.t., resulted in a rapid color change from dark green to orange, with some unreacted sulfur remaining at the bottom of the flask. Recovery of the sulfur showed that only half an equivalent of sulfur $\left(S_{8}\right)$ reacted with 1. Solvent removal produced a somewhat sticky yellow solid, the usual form of crude products due to the greasy, lipophilic nature of the $\mathrm{Tp}^{\mathrm{i} \mathrm{Pr}_{2}}$ ligand. Curiously, crystallization attempts from various solvent mixtures $\left(\mathrm{Et}_{2} \mathrm{O} / \mathrm{THF} ; \mathrm{Et}_{2} \mathrm{O} /\right.$ hexane $)$ first produced small amounts of yellow crystals, which proved to be elemental sulfur, orthorhombic and monoclinic forms. From further crystallization attempts only a few suitable crystals for X-ray analysis could be isolated, which were shown to be $\operatorname{Sm}\left(\mathrm{Tp}^{\mathrm{iPr}}\right)$ $\left(\kappa^{1}-3,5-{ }^{\mathrm{i}} \mathrm{Pr}_{2} \mathrm{Hpz}\right)\left(\mathrm{S}_{5}\right)(3)$, Scheme 1 . The observation that the first crystalline materials were elemental sulfur indicated either that the amount of sulfur in solution was more than needed for the reaction or that some intermediate Sm-polysul- 


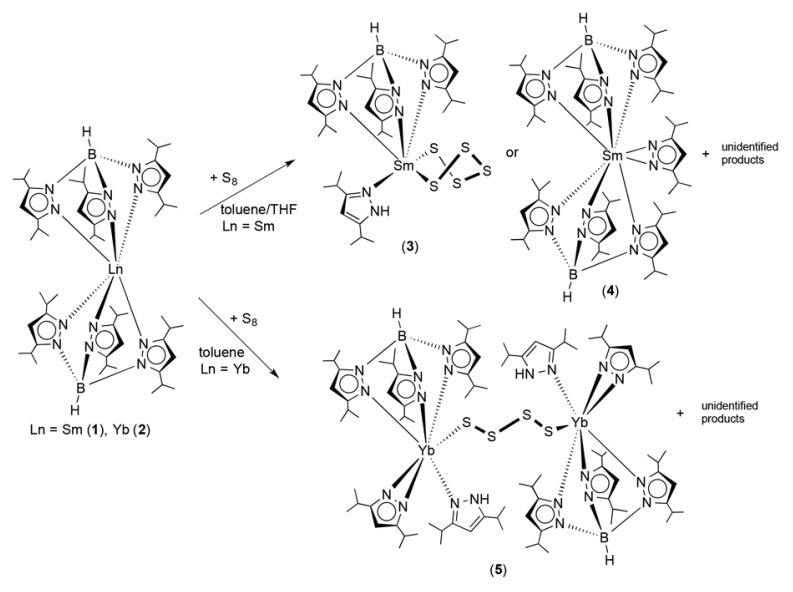

Scheme 1 Reactions of $\operatorname{Ln}\left(\mathrm{Tp}^{\mathrm{iPr}}\right)_{2}(\mathrm{Ln}=\mathrm{Sm}$, Yb) with elemental sulfur.

fide species underwent sulfur extrusion. To answer the question as to the stoichiometric amount of sulfur needed to oxidize the precursor $\mathrm{Sm}\left(\mathrm{Tp}^{\mathrm{iPr}}\right)_{2}$ compound, a second reaction was carried out which showed that bleaching of the dark green THF solution of $\mathbf{1}$ at RT occurred after the addition of only 1 equiv. of sulfur (S) per Sm(II). Crystallization of the crude, yellow, sticky solid produced a small amount of white crystals which proved to be $\operatorname{Sm}\left(\mathrm{Tp}^{\mathrm{iPr}}\right)_{2}\left(\kappa^{2}-3,5-{ }^{\mathrm{i}} \mathrm{Pr}_{2} \mathrm{pz}\right)$ (4, Scheme 1). Unfortunately, numerous other crystallization attempts from various mixed solvent system did not yield crystals suitable for X-ray analysis, hence the nature of the sulfur containing species from this second reaction remain unknown.

The analogous reaction of $\mathrm{Yb}\left(\mathrm{Tp}^{\mathrm{iPr}}\right)_{2}$ (2) with sulfur was found to be more straightforward. Stirring of equimolar amounts $(\mathrm{Yb}: \mathrm{S})$ of 2 and sulfur in toluene for $24 \mathrm{~h}$ caused a color change from bright red to amber.

Recrystallization of the reaction product from $n$-pentane afforded orange, cube-like single crystals of $5 \cdot 2 \mathrm{C}_{5} \mathrm{H}_{12}$ suitable for X-ray diffraction.

The constitution and molecular structure of compounds $\mathbf{3}$, 4 and 5 were revealed by single crystal X-ray diffraction studies. The structures of $\mathbf{3}$ and $\mathbf{5}$ are shown in Fig. 1 and 2, respectively. The structure of compound 4 can be found in the ESI. + The structure of 3 consists of a normal $\kappa^{3}-\mathrm{Tp}^{\mathrm{iPr}_{2}}$ ligand, a coordinated, neutral $\kappa^{1}-3,5{ }^{\mathrm{i}} \mathrm{Pr}_{2} \mathrm{Hpz}$ ligand, and the electronic demand of the Sm(III) ion is satisfied by the dianionic $\mathrm{S}_{5}{ }^{2-}$ polysulfide ligand. The most remarkable feature of the compound is the conformation of the $\mathrm{SmS}_{5}$ six-membered ring. As opposed to the classical chair conformation found in transition-metal complexes containing the $\mathrm{MS}_{5}$ moiety, such as $\mathrm{Cp}_{2} \mathrm{MS}_{5}(\mathrm{M}=\mathrm{Ti}, \mathrm{Zr}, \mathrm{Hf}),\left[\mathrm{FeS}_{5}(\mu-\mathrm{S})\right]_{2}{ }^{2-}$ and $\left[\mathrm{Pt}\left(\mathrm{S}_{5}\right)_{3}\right]^{2-},{ }^{25-30}$ and that in cyclo- $\mathrm{S}_{6},{ }^{31}$ the $\mathrm{SmS}_{5}$ six-membered ring adopts the twist-boat conformation. It is noteworthy that a similar ring conformation was also observed in the related actinide f-element compound, $\left(\mathrm{C}_{5} \mathrm{Me}_{5}\right)_{2} \mathrm{ThS}_{5},{ }^{32}$ and may signal that the twist-boat conformation is a common feature of $\mathrm{An} / \mathrm{LnS}_{5}$ containing compounds. The similarities between the two structures extend to the $\mathrm{M}-\mathrm{S}$ distances as well. Interestingly not only the terminal $\mathrm{S}$ (alpha) atoms are bonded to $\mathrm{Sm}(\mathrm{Sm}-\mathrm{S} 1 / \mathrm{S} 5$

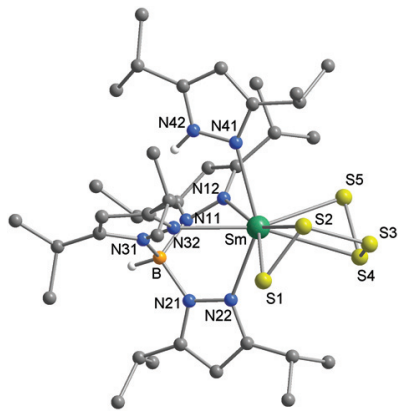

Fig. 1 Molecular structure of 3 in the crystal showing the atom-labeling scheme. Selected bond lengths [Å] and angles [ $\left.{ }^{\circ}\right]$ : Sm-N12 2.533(2), Sm-N22 2.531(2), Sm-N32 2.509(2), Sm-N41 2.606(2), Sm-S1 2.755(1), Sm-S5 2.792(1), Sm-S2 2.952(1), Sm-S4 3.090(1); Sm-S1-S2 74.66(3), Sm-S5-S4 77.88(3), S1-Sm-S5 113.10(2), S1-S2-S3 106.63(5), S5-S4S3 108.54(5), S2-S3-S4 101.42(4).

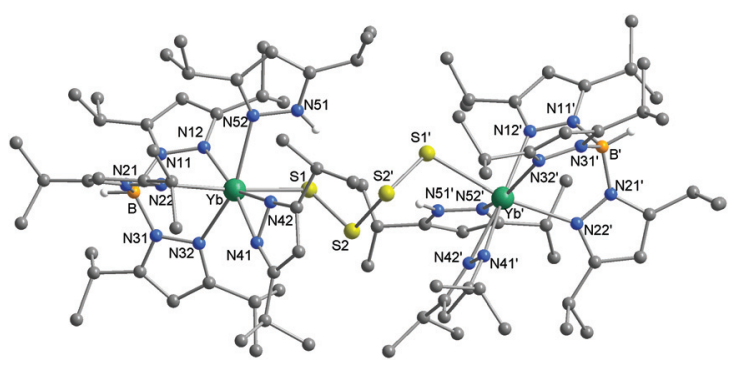

Fig. 2 Molecular structure of 5 in the crystal showing the atom-labeling scheme. Symmetry operator to generate equivalent atoms: ' $2-x, y, 1-$ $z$. Selected bond lengths $[\AA \AA]$ and angles [ $\left.{ }^{\circ}\right]$ : $\mathrm{Yb}-\mathrm{N} 12$ 2.423(7), $\mathrm{Yb}-\mathrm{N} 22$ 2.421(7), Yb-N32 2.406(6), Yb-N41 2.304(7), Yb-N42 2.244(7), Yb-N52 2.443(7), Yb-S1 2.703(2), S1-S2 2.072(3), S2-S2' 2.044(5), Yb-S1-S2 106.0(1), S1-S2-S2' 106.8(1), S1-S2-S2'-S1' dihedral angle 69.5(6).

$2.755(1) / 2.792(1) \AA)$ but also the two S(beta) atoms (Sm-S2/S4 $2.952(1) / 3.090(1) \AA)$; the corresponding distances in the $C_{2}$ symmetric $\left(\mathrm{C}_{5} \mathrm{Me}_{5}\right)_{2} \mathrm{ThS}_{5}$ compound are $\mathrm{Th}-\mathrm{S} 1 / \mathrm{S} 1^{\prime}$ and Th-S2/S2', 2.768(4) and 3.036(4), respectively. In the transition-metal $\mathrm{MS}_{5}$ compounds with the chair conformation only the terminal sulfurs of the chelating $\mathrm{S}_{5}{ }^{2-}$ ligand are coordinated to the metal.

Compound $\mathbf{5}$ is a dinuclear ytterbium(III) polysulfide complex in which two $\left[\mathrm{Yb}\left(\mathrm{Tp}^{\mathrm{iPr}}\right)\left(\kappa^{1}-3,5{ }^{-}{ }^{\mathrm{i}} \mathrm{Pr}_{2} \mathrm{Hpz}\right)\left(\kappa^{2}-3,5{ }^{\mathrm{i}} \mathrm{Pr}_{2} \mathrm{pz}\right)\right]$ moieties are bridged by a $\mu-\mathrm{S}_{4}{ }^{2-}$ ligand. Each formally 7 -coordinated ytterbium ion is bonded to an original $\kappa^{3}-\mathrm{Tp}^{\mathrm{iPr}}$ ligand as well as a neutral $\kappa^{1}-3,5-{ }^{\mathrm{i}} \mathrm{Pr}_{2} \mathrm{Hpz}$ ligand and an anionic $\kappa^{2}-3,5{ }^{\mathrm{i}} \mathrm{Pr}_{2} \mathrm{pz}$ ligand which were formed as a result of ligand fragmentation. ${ }^{33}$ Certainly this accounts for the fairly low isolated yield of compound 5 (32\%). In accordance with the overall $C_{2}$-symmetry of the molecule, the ${ }^{11} \mathrm{~B}$ NMR spectrum of 5 shows only a single resonance $(\delta=-4.4 \mathrm{ppm})$. The conformation of the bridging $\mu-\mathrm{S}_{4}{ }^{2-}$ ligand closely resembles that of the tetrasulfide dianion in crystalline $\mathrm{Na}_{2} \mathrm{~S}_{4}{ }^{34,35}$ with a dihedral angle of $69.5(6)^{\circ}\left(97.81^{\circ}\right.$ in $\left.\mathrm{Na}_{2} \mathrm{~S}_{4}\right)$. The $\mathrm{Yb}-\mathrm{S}$ bond length is $2.703(2) \AA$. 


\section{Conclusions}

In summarizing the results reported here, although formation of compounds 3,4 and 5 was accompanied by $\mathrm{Tp}^{\mathrm{iPr}_{2}}$ ligand fragmentation, their isolation underscores the following points: 1 . The fact that $\operatorname{Sm}\left(\mathrm{Tp}^{\mathrm{iPr}}\right)_{2}\left(\kappa^{2}-3,5-{ }^{\mathrm{i}} \mathrm{Pr}_{2} \mathrm{pz}\right)(\mathbf{4})$ contains a $\kappa^{2}$-pyrazolide wedged between two $\left(\mathrm{Tp}^{\mathrm{iPr}}\right)_{2}$ ligand, holds out the hope that under suitable conditions, highly reducing $\mathrm{Ln}\left(\mathrm{Tp}^{\mathrm{iPr}}\right)_{2}$ compounds might be able to bind and activate interesting small molecules like $\mathrm{CO}, \mathrm{CO}_{2}$, etc. 2 . The very rapid reaction of compound $\mathbf{1}$ with sulfur and the rather non-selective formation of compound 3 underlines the stronger reducing power of the Sm(II) precursor compared with $\mathrm{Yb}$ (II). Thus, the reactivity of $\mathrm{Yb}\left(\mathrm{Tp}^{\mathrm{iPr}}\right)_{2}$ is significantly reduced and allows for the more straightforward preparation of the tetrasulfide derivative 5. 3. The successful isolation and structural characterization of the first lanthanide(III) polysulfide complexes, $\operatorname{Sm}\left(\mathrm{Tp}^{\mathrm{iPr}}\right)\left(\kappa^{1}-3,5-{ }^{\mathrm{i}} \mathrm{Pr}_{2} \mathrm{Hpz}\right)\left(\mathrm{S}_{5}\right)$ (3) and $\left(\mu-\mathrm{S}_{4}\right)\left[\mathrm{Yb}\left(\mathrm{Tp}^{\mathrm{iPr}}\right)^{-}\right.$ $\left.\left(\kappa^{1}-3,5-{ }^{\mathrm{i}} \mathrm{Pr}_{2} \mathrm{Hpz}\right)\left(\kappa^{2}-3,5-{ }^{\mathrm{i}} \mathrm{Pr}_{2} \mathrm{pz}\right)\right]_{2}$ (5) encourages the quest for more rational synthesis of similar lanthanide polysulfides and the study of their bonding characteristics. Such studies are underway in our laboratories.

This work was financially supported by the Otto-von-Guericke-Universität Magdeburg and the University of Alberta. JT thanks Jackie Kiplinger (Los Alamos National Laboratory) for useful discussions and we thank the reviewers for helpful comments.

\section{Experimental section}

\section{Synthesis of complex 3}

(i) Sulfur flakes $\left(56.7 \mathrm{mg}, 0.22 \mathrm{mmol} \mathrm{S}_{8}\right)$ were added to a stirred toluene solution of $1(239 \mathrm{mg}, 0.22 \mathrm{mmol})$ at r.t. After only about a minute the color changed from dark green to orange, with substantial amount of unreacted sulfur (ca. $28 \mathrm{mg}$ ) at the bottom of the round-bottom flask. Decantation from the unreacted sulfur, followed by solvent removal gave a slightly sticky, yellow solid. Extraction with $n$-pentane left behind a small amount of pale yellow solid, shown to be sulfur (orthorhombic) by X-ray diffraction on crystals obtained from $\mathrm{Et}_{2} \mathrm{O} / \mathrm{THF}$ solvent mixture. Crystallization attempts from $n$-pentane only produced powdery solids. Crystallization from $\mathrm{Et}_{2} \mathrm{O} / n$-hexane solvent mixtures, two attempts, produced small amounts of yellow crystals which were again shown to be sulfur (orthorhombic and monoclinic forms). Ultimately from THF/hexamethyldisiloxane (HMDSO), a small number of pale yellow crystals were harvested, which proved to be compound 3 .

(ii) Small amounts of sulfur flakes were added to a stirred THF solution of $1(523 \mathrm{mg}, 0.484 \mathrm{mmol})$ at r.t. After the addition of only $16 \mathrm{mg}(0.5 \mathrm{mmol}$ of $\mathrm{S})$ the original dark green color changed to orange. Solvent removal gave a slightly sticky, yellow solid. Crystallizations from $\mathrm{Et}_{2} \mathrm{O} / n$-hexane solvent mixtures, twice produced crystals of compound 3. Numerous other crystallization attempts failed to produce crystals suitable for $\mathrm{X}$-ray analysis and failed to give sulfur-containing material.

\section{Synthesis of complex 5}

Powdered sulfur (14 mg, $0.44 \mathrm{mmol}$ ) was added to a solution of compound 2 (484 mg, $0.44 \mathrm{mmol})$ in toluene $(20 \mathrm{ml})$. After $24 \mathrm{~h}$ stirring at r.t. the color had changed from bright red to amber. Removal of the solvent and recrystallization from $n$-pentane $\left(15 \mathrm{ml},-5{ }^{\circ} \mathrm{C}\right)$ afforded $152 \mathrm{mg}(32 \%)$ of 5 as orange, cube-like crystals. Mp. $130{ }^{\circ} \mathrm{C} .{ }^{1} \mathrm{H}$ NMR (toluene- $d_{8}$, $400 \mathrm{MHz}$ ): $\delta 10.53$ (s br, 6H, pz), 5.40 (s br, $2 \mathrm{H}, \mathrm{C}-H^{\mathrm{i}} \mathrm{Pr}$ ), 3.04 (s, 2H, pz), 2.0-2.2 (s br, 2H, B-H), 2.38 (s, 12H, $\left.\mathrm{CH}_{3}{ }^{\mathrm{i}} \mathrm{Pr}\right), 1.23$ (m, $12 \mathrm{H}, \mathrm{CH}_{2}$ of $n$-pentane), 0.87 (t, $12 \mathrm{H}, \mathrm{CH}_{3}$ of $n$-pentane), -0.20 (s br, 6H, $C-\mathrm{H}{ }^{\mathrm{i}} \mathrm{Pr}$ ), -0.65 (s, 2H, pz), -0.99 (s, 2H, $C-\mathrm{H}$ $\left.{ }^{\mathrm{i}} \mathrm{Pr}\right),-2.33\left(\mathrm{~s} \mathrm{br}, 12 \mathrm{H}, \mathrm{CH}_{3}{ }^{\mathrm{i}} \mathrm{Pr}\right),-6.22$ (s br, 48H, $\mathrm{CH}_{3}{ }^{\mathrm{i}} \mathrm{Pr}$ ), -12.00 (s br, $\left.48 \mathrm{H}, \mathrm{CH}_{3}{ }^{\mathrm{i}} \mathrm{Pr}\right) .{ }^{13} \mathrm{C}$ NMR (toluene- $\left.d_{8}, 100 \mathrm{MHz}\right): \delta=$ 173.8 (q- $C$ pz), 150.9 (q- $C$ pz), $102.3(C H$ pz) $87.3(C H \mathrm{pz}), 34.4$ $\left(\mathrm{CH}_{2}\right.$ of $n$-pentane), $27.3\left(\mathrm{CH}{ }^{\mathrm{i}} \mathrm{Pr}\right), 23.5\left(\mathrm{CH}_{3}{ }^{\mathrm{i}} \mathrm{Pr}\right), 22.7\left(\mathrm{CH}_{2}\right.$ of $n$-pentane), $21.5\left(\mathrm{CH}_{3}{ }^{\mathrm{i}} \mathrm{Pr}\right), 19.5\left(C-\mathrm{H}{ }^{\mathrm{i}} \mathrm{Pr}\right), 15.6\left(\mathrm{CH}_{3}{ }^{\mathrm{i}} \mathrm{Pr}\right)$, $14.1\left(\mathrm{CH}_{3}\right.$ of $n$-pentane). ${ }^{11} \mathrm{~B}$ NMR (toluene- $\left.d_{8}, 128 \mathrm{MHz}\right): \delta=$ $-4.4 \mathrm{ppm}$. Elemental analysis calcd for $\mathrm{C}_{100} \mathrm{H}_{178} \mathrm{~B}_{2} \mathrm{~N}_{20} \mathrm{~S}_{4} \mathrm{Yb}_{2}$ $\left(5 \cdot 2 \mathrm{C}_{5} \mathrm{H}_{12}\right)$ : C 55.69, $\mathrm{H}$ 8.32, $\mathrm{N}$ 12.99; found $\mathrm{C} 56.04, \mathrm{H} 8.64$, $\mathrm{N} 12.50$.

\section{References}

1 W. Biltz, Z. Elektrochem., 1911, 17, 668.

2 J. Flahaut, M. Guitard and M. Patrie, Bull. Soc. Chim. Fr., 1959, 1917.

3 Y. Yanagisawa and S. Kume, Mater. Res. Bull., 1986, 21, 379.

4 L. C. Otero-Diaz, M. J. Torralvo and R. M. Rojas, Solid State Ionics, 1993, 63-65, 318.

5 R. Tamazyan, S. van Smaalen, I. G. Vasilyeva and H. Arnold, Acta Crystallogr., Sect. B: Struct. Sci., 2003, 59, 709.

6 T. Doert, C. Graf, P. Laux and T. Schleid, Z. Anorg. Allg. Chem., 2007, 633, 2719.

7 T. Doert, C. Graf, I. G. Vailyeva and W. Schnelle, Inorg. Chem., 2012, 51, 282.

8 A. W. Webb and H. T. Hall, Inorg. Chem., 1970, 9, 1084.

9 C. J. Müller, U. Schwarz and T. Doert, Z. Anorg. Allg. Chem., 2012, 638, 2477, and references cited therein.

10 W. J. Evans, G. W. Rabe, J. W. Ziller and R. J. Doedens, Inorg. Chem., 1994, 33, 2719.

11 J. H. Melman, T. J. Emge and J. G. Brennan, Chem. Commun., 1997, 2269.

12 D. Freedman, T. J. Emge and J. G. Brennan, Inorg. Chem., 1999, 38, 4400.

13 J. H. Melman, T. J. Emge and J. G. Brennan, Inorg. Chem., 1999, 38, 2117.

14 M. Fitzgerald, T. J. Emge and J. G. Brennan, Inorg. Chem., 2002, 41, 3528.

15 Z. Zhang, L. Zhang, Y. Li, L. Hong, Z. Chen and X. Zhou, Inorg. Chem., 2010, 49, 5715.

16 K. Norton, S. Banerjee, S. Das, L. Hübner, T. J. Emge and J. G. Brennan, Dalton Trans., 2010, 39, 6794.

17 J. F. Corbey, M. Fang, J. W. Ziller and W. J. Evans, Inorg. Chem., 2015, 54, 801. 
18 Y. Li, C. Pi, J. Zhang, X. Zhou, Z. Chen and L. Weng, Organometallics, 2005, 24, 1982.

19 N. Arleth, S. Bestgen, M. T. Gamer and P. W. Roesky, J. Am. Chem. Soc., 2014, 136, 14023.

20 J. Li, J. Hao and C. Cui, Dalton Trans., 2015, 44, 767.

21 D. J. Berg, C. J. Burns, R. A. Andersen and A. Zalkin, Organometallics, 1989, 8, 1865.

22 A. Recknagel, M. Noltemeyer, D. Stalke, U. Pieper, H.-G. Schmidt and F. T. Edelmann, J. Organomet. Chem., 1991, 411, 347.

23 A. Momin, L. Carter, Y. Yang, R. McDonald, S. Essafi, F. Nief, I. Del Rosal, A. Sella, L. Maron and J. Takats, Inorg. Chem., 2014, 53, 12066.

24 M. Kühling, C. Wickleder, M. J. Ferguson, C. G. Hrib, R. McDonald, M. Suta, L. Hilfert, J. Takats and F. T. Edelmann, New J. Chem., 2015, 39, 7617.

25 H. Köpf, B. Block and M. Schmidt, Chem. Ber., 1968, 101, 272.

26 E. F. Epstein, I. Bernal and H. Köpf, J. Organomet. Chem., 1971, 26, 229.

27 E. G. Muller, J. L. Petersen and L. F. Dahl, J. Organomet. Chem., 1976, 111, 91.
28 M. Draganjac and T. B. Rauchfuss, Angew. Chem., Int. Ed. Engl., 1985, 24, 742, and references therein.

29 A. Müller and E. Diemann, Adv. Inorg. Chem., 1987, 31, 89.

30 N. Takeda, N. Tokito and R. Okazaki, Top. Curr. Chem., 2003, 231, 153.

31 M. Schmidt, B. Block, H. D. Block, H. Köpf and E. Wilhelm, Angew. Chem., Int. Ed. Engl., 1968, 7, 632.

32 D. A. Wrobleski, D. T. Cromer, J. V. Ortiz, T. B. Rauchfuss, R. R. Ryan and A. P. Sattelberger, J. Am. Chem. Soc., 1986, 108, 174.

33 Fragmentation of substituted Tp ligands is well documented (A. Domingos, M. R. J. Elsegood, A. C. Hillier, G. Lin, S. Y. Liu, I. Lopes, N. Marques, G. H. Maunder, R. McDonald, A. Sella, J. W. Steed and J. Takats, Inorg. Chem., 2002, 41, 6761, and references therein), but it seems to be even more prevalent with the $\mathrm{Tp}^{\mathrm{iPr}}{ }_{2}$ ligand as seen in reactivity studies of $\operatorname{Ln}\left(\mathrm{Tp}^{\mathrm{iPr}}{ }_{2}\right)_{2}(\mathrm{Ln}=\mathrm{Sm}, \mathrm{Tm})$ (J. Takats, unpublished work.).

34 R. Tegman, Acta Crystallogr., Sect. B: Struct. Crystallogr. Cryst. Chem., 1973, 29, 1463.

35 S. J. Chadwell, D. Rickard and G. W. Luther III, Electroanalysis, 2001, 13, 21. 